\title{
Structural Investigation of Bistrifluron Using X-Ray Crystallography, NMR Spectroscopy, and Molecular Modeling
}

\author{
Joon Kwan Moon, Jeong-Han Kim,'Sangkee Rhee, Gangbeom Kim, ${ }^{\dagger}$ \\ Hoseop Yun, ${ }^{\dagger}$ Bong-Jin Chung, ${ }^{\ddagger}$ Sangsan Lee,, and Yoongho Lim ${ }^{\# .}$ \\ School of Agricultural Biotechologv, Seoul National Thiversin, Sitwon 441-744, Korea \\ -Department of Wolecular Science and Technologv. Ajon Thiversit, Sitwon 442-749, Korea \\ IDonghu Reseach hastitute, Donghuhanong (hemical he., Whasung 445-960, Kored \\ SSiupercomputing ('enter; Korea Institute of Science and Technology Information, Daejon 305-350, Korea \\ "Department of Appled Biology and Chemisty. Bio Molecular Informatics Center, Konkuk Thiversity, Seoul 143-701, Korea \\ Received Fehnary 21, 2002
}

\begin{abstract}
A nen insecticide. bistrilluron acts as an inhibitor of insect development and interferes with the culicle lemmation of insects. Sine it shows low acule oral and dermal toxicities it ean be one of potent insecticides. Based on X-ray erystallography, NMR spectroseopy and molecular modeling, the struetural studies of bistritluron have ben carried out.
\end{abstract}

Key Words : Bistrifluron. X-Ray crystallography, NMR spectroscopy, Molecular modeling

\section{Introduction}

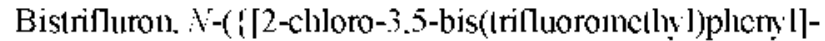
amino; carbonyl)-2.6-difluorobcn/amide. is a new benzov]plenylurea insecticide developed by Dongbu-lannong Chemical Co.. Korea (Figure 1). It is found to be an inlibitor of insect development and acts by interference with the formation of the insects culicle. probably by inactivating of the chitin synthetase as the ollher benzoy Ipheny lureas do. ${ }^{1}$ It is active against lepidopteran pest. whitelly as an insect growth regulator. In addition. it can be widely used on apple. Brassica leaf vegetables. 10mato. persimmon and other fruils. The moulting process is thus inhibitcd. leading to deall.:- The water solubility is approximatcly $0.03 \mathrm{mg} / \mathrm{L}$ and its vapor pressure. $2.05 \times 10^{8}$ torr. It las low acuic oral and dernal toxicity (rat) of $>5.000 \mathrm{mg} / \mathrm{kg}$ and $>2.000 \mathrm{mg} / \mathrm{kg}$. respectively.

Since the infonmation about its structure may lielp the modification for the development of more potent pesticides. authors report the results of its three dimensional structural sludies here.

\section{Materials and Methods}

Chemicals. Bistrilluron (purity 97.3\%) was obtained from Dongbulannong chemical Co. All solvents used for preparing crystal were reagent grade or betler (Duksan. Korea).

$\mathrm{X}$-Ray crystallography. A crystal sample was prepared in a mixture of dichloromethane and hexanc. Data collection was perfonned wilh MoK $\alpha$, radiation $(\lambda=0.71073 \dot{A})$ on a MXC3 Diffractomeler (Mac Science. Japan) cquipped witlı

"Coresponding authors. Yoongho Lim(Phone: $+82-2-450-3760$, lax: +82-2-453-3761, e-mail: yoonghw a konkuk ackr), Jeongllan Kim(Phone: +82-31-290-2404, Fax: +82-31-293-8608, e-mail: kijh2404ta $a$ snu.ac.ki) an incident beam graplite monocliromator. The unit cell parameters and the oricntation matrix for data collection were obtained from the least-squares refinement using the scling angles of 15 refloctions in the range $20^{\circ}<2 \theta\left(\mathrm{MoK} \alpha_{1}\right)<$ $28^{\circ}$. Intensity data were collected with the $\omega-2 \theta$ scan techniques. The intensitics of two standard reflections slowed no significant dev iations during the data collection.

The initial positions for all non lydrogen atoms were oblaincd by using direct methods of the SHELXS-86 program. ${ }^{3}$ Tlic stnucture was refincd by full matrix least-squares technique with the usc of the SHELXL-93 program. "Arrisotropic thermal motion for non-lydrogen atoms and isotropic extinction parameters were included. The final cycle of refinement performed on $\mathrm{FO}^{2}$ with all 3081 urique reflections afforded residuals wR $2=0.1538$ and the conventional $\mathrm{R}$ index based on the reflections having $\mathrm{Fo}>2 \sigma\left(\mathrm{Fo}^{-}\right)$was 0.0640

NMR spectroscopy. The ${ }^{1} H$ NMR spectrum was obtained on a Bruker DRX 600 (14.1 T. Karlsrulic. Germany) and other NMR spectra were obtained on a Bruker Atarice 400 (9.4 T. Karlstulic. Gernany) insinument in $\mathrm{CDCl}_{3}$ and DMSO-d . For the 'H-NMR experiment. 32 transients were acquired with $1 \mathrm{sec}$ relaxation delay using $32 \mathrm{~K}$ data points.<smiles>O=C(NC(=O)c1c(F)cccc1F)Nc1cc(C(F)(F)F)cc(C(F)(F)F)c1Cl</smiles>

Figure 1. The structure and nomenclature of bistrilluron. 
and the $90^{\circ}$ pulse was $12.8 \mu$ sec. with spectral width of $6.000 \mathrm{~Hz}$. For the ${ }^{1.3} \mathrm{C}-\mathrm{NMR}$ and DEPT ${ }^{5}$ experiments. 3000 transients were acquired with a $2 \mathrm{sec}$ relaxation delay using $6+\mathrm{K}$ data points, and the $90^{\circ}$ pulse was $9.8 \mu \mathrm{sec}$ with spectral width of $22.000 \mathrm{~Hz}$. Two-dimensional spectra were acquired with 2048 data points in 12 and 256 in tl increments. The COSY." HMQC. and HMBC ${ }^{8}$ spectra were collected with the magnitude method. and the NOESY ${ }^{y}$ spectrum, with the plase sensitive mode.

Molecular modeling. All computational calculations were perfonned using Accelrys software (San Diego. CA) on a Silicon Graphics O2 R12000 workstation, where the consistent-ralence forcefield (crff) and the extensible-systematic forcefield (esff) were used for $500 \mathrm{psec}$

\section{Results and Discussion}

X-Ray crystallography: ORTEP diagram and numbering scheme for bistrifluron is slown in Figure 2. Atomic coordinates and equivalent isotropic displacement parameters for bistrifluron are listed in Table l. Crystal size was approximately $0.30 \times 0.20 \times$ $0.14 \mathrm{~mm}$ and unit cell was triclinic. The triclinic cell pariumeters and calculated volumes are $\mathrm{a}=7.794(3) \mathrm{A} . \mathrm{b}=15.272(6)$ A. $c=15.288(6) \AA . \alpha=89.00(3)^{\circ} . \beta=77.6+(3)^{\circ} . \gamma=79.12(3)^{\circ}$.

The sy stematic extinction was indicative of the space group $P_{\overline{\mathrm{T}}}$. Bond length of carbon-carbon carbon-fluonine. and carbonchlorine is about 1.495 .1 .346 and $1.731 \mathrm{~A}$. respectively: Double bond length of carbon-oxygen is 1.218 A. Bond length of difluorobenzoyl ring carbons is $1.378 \mathrm{~A}$ and phenyl ring carbons is $1.386 \mathrm{~A}$.

Bond angle of $\mathrm{C}-\mathrm{F} \mathrm{sp}{ }^{3}$ hybrid is $106.2^{\circ}$ and $\mathrm{sp}^{2}$ hybrid of benzene ring is $120^{\circ}$. Torsion angle of $\mathrm{C} 5-\mathrm{C} 6-\mathrm{C} 7-\mathrm{Nl}$ is 56.6 and $\mathrm{C} 10-\mathrm{C} 9-\mathrm{N} 2-\mathrm{C} 8$ is 11.9 . Ring $\mathrm{A}$ and ring $\mathrm{B}$ are not in the same plane. Figure 3 shows the packing mode of molecules in the unit cell. Two molecules of bistrifluron are packed at the opposite direction.

NMR spectroscopy. In order to investigate the three dimensional stnicture using NMR. nOe has been used. Unfortunately: bistrifluron does not contain sufficient protons

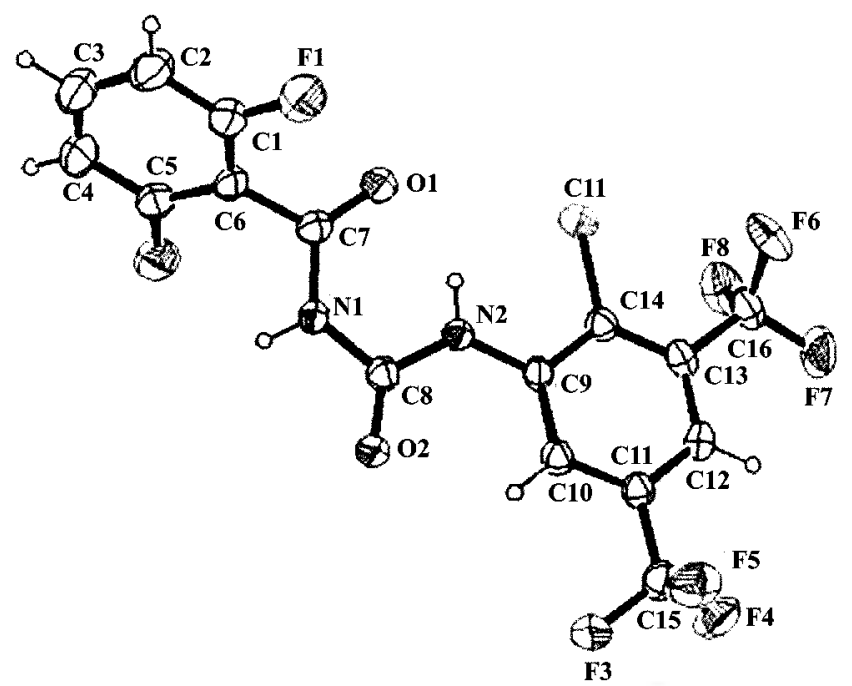

Figure 2. ORILP diagram and numbering scheme lor bistrifluron.
Table 1. Atomic coordinales $\left(\times 10^{t}\right)$ and equivalent isotropic displacement paramelers $\left(\AA^{2} \times 10^{3}\right)$ lor bistrilluron (Lisd in parentheses)

\begin{tabular}{|c|c|c|c|c|}
\hline & $x$ & $y$ & $\%$ & U (ecl) \\
\hline$C(1)$ & $4676(9)$ & $4244(4)$ & $1013(4)$ & $69(2)$ \\
\hline$C(2)$ & $4958(10)$ & $5066(4)$ & $1241(4)$ & $84(2)$ \\
\hline$C(3)$ & $3523(1.3)$ & $5762(5)$ & $1.365(5)$ & $97(2)$ \\
\hline$C(4)$ & $1866(11)$ & $5651(4)$ & $1272(5)$ & $93(2)$ \\
\hline$C(5)$ & $1648(10)$ & $4803(4)$ & $1058(4)$ & $71(2)$ \\
\hline$C(6)$ & $3052(9)$ & $4(184(3)$ & $919(3)$ & $60(2)$ \\
\hline$C(7)$ & $2869(8)$ & $3182(3)$ & $625(3)$ & $59(1)$ \\
\hline$C(8)$ & $1233(7)$ & $1940(3)$ & $1119(3)$ & $49(1)$ \\
\hline $\mathrm{C}(9)$ & $2307(6)$ & $545(3)$ & $204(3)$ & $44(1)$ \\
\hline$C(10)$ & $1551(6)$ & $-25(3)$ & $821(3)$ & $48(1)$ \\
\hline$C(11)$ & $1707(6)$ & $-908(3)$ & $600(3)$ & $47(1)$ \\
\hline$C(12)$ & $2567(6)$ & $-1237(3)$ & $-252(3)$ & $52(1)$ \\
\hline$C(13)$ & $3324(6)$ & $-680(3)$ & $-879(3)$ & $51(1)$ \\
\hline$C(14)$ & $3213(6)$ & $207(3)$ & $-646(3)$ & $47(1)$ \\
\hline$C(15)$ & $984(8)$ & $-1529(4)$ & $1283(4)$ & $59(1)$ \\
\hline$C(16)$ & $4239(8)$ & $-1048(4)$ & $-1797(4)$ & $66(2)$ \\
\hline $\mathrm{Cl}(1)$ & $4220(2)$ & $916(1)$ & $-1395(1)$ & $63(1)$ \\
\hline $\mathrm{F}(1)$ & $6083(5)$ & $3561(2)$ & $899(3)$ & $97(1)$ \\
\hline$F(2)$ & $39(5)$ & $4685(2)$ & $950(2)$ & $93(1)$ \\
\hline$F(3)$ & $-405(4)$ & $-1119(2)$ & $1894(2)$ & $75(1)$ \\
\hline$F(4)$ & $424(5)$ & $-2186(2)$ & $927(2)$ & $90(1)$ \\
\hline$F(5)$ & $2196(5)$ & $-1913(2)$ & $1739(2)$ & $88(1)$ \\
\hline$F(6)$ & $5950(5)$ & $-969(3)$ & $-2008(2)$ & $92(1)$ \\
\hline$F(7)$ & $4227(6)$ & $-1914(2)$ & $-1874(2)$ & $104(1)$ \\
\hline$F(8)$ & $3473(5)$ & $-650(2)$ & $-2427(2)$ & $91(1)$ \\
\hline$N(1)$ & $1563(6)$ & $2808(2)$ & $1162(3)$ & $54(1)$ \\
\hline$N(2)$ & $2241(5)$ & $1448(2)$ & $399(2)$ & $51(1)$ \\
\hline$O(1)$ & $3887(6)$ & $2803(2)$ & $-39(3)$ & $82(1)$ \\
\hline$O(2)$ & $143(5)$ & $1686(2)$ & $1708(2)$ & $57(1)$ \\
\hline
\end{tabular}

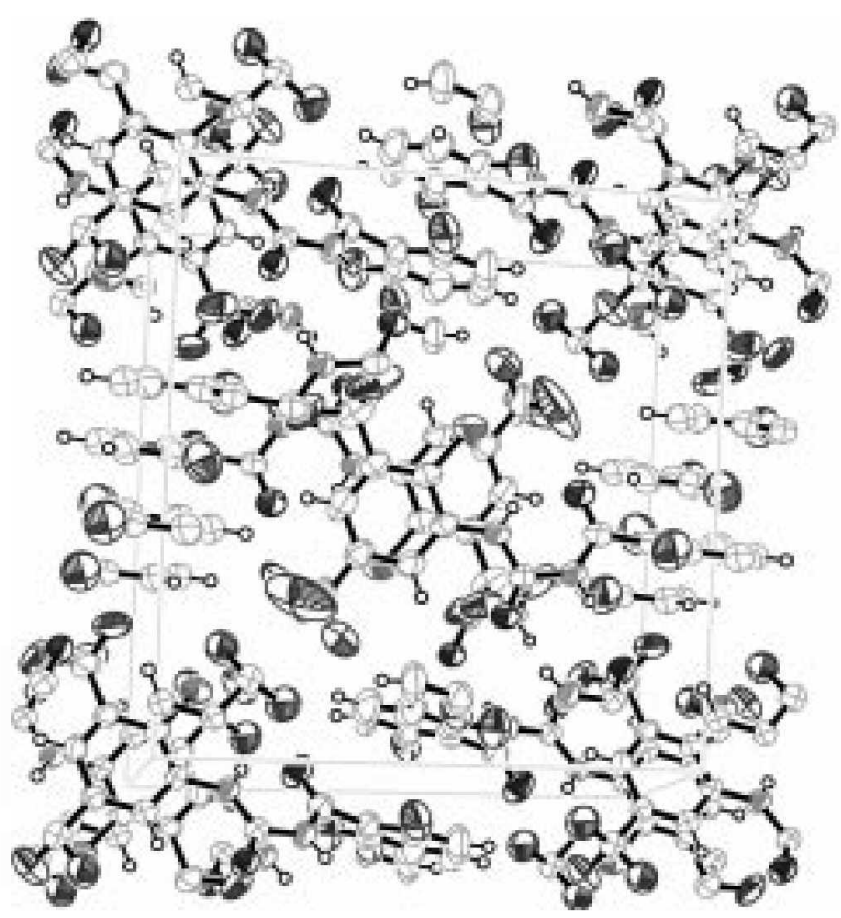

Figure 3. Packing mode in the unit cell tor histrifluron. 
Table 2. Complete assignments of the ${ }^{\mathrm{H}} \mathrm{H}$ and ${ }^{19} \mathrm{C}$ NMR data

\begin{tabular}{cccc}
\hline$\delta^{13} \mathrm{C} \mathrm{ppm}$ & $\mathrm{CH}_{{ }^{\prime \prime}}$ & $\delta^{{ }}{\mathrm{H} \mathrm{ppm}(\mathrm{J} \mathrm{Hz})^{b}}^{\text {assignments }}$ \\
\hline 111.6 & $\mathrm{~d}$ & $7.08(\mathrm{~m})$ & $\mathrm{C} 2.4$ \\
118.1 & $\mathrm{~d}$ & $7.75(\mathrm{~d} .1 .7)$ & $\mathrm{C} 12$ \\
120.8 & $\mathrm{~d}$ & $8.95(\mathrm{~d} .1 .7)$ & $\mathrm{C} 10$ \\
121.4 & $\mathrm{~s}$ & - & $\mathrm{C} 9$ \\
123.2 & $\mathrm{~s}$ & - & $\mathrm{C} 13$ \\
124.1 & $\mathrm{~s}$ & - & $\mathrm{C} 11$ \\
128.7 & $\mathrm{~s}$ & - & $\mathrm{C} 15$ \\
129.1 & $\mathrm{~s}$ & - & $\mathrm{C} 16$ \\
133.4 & $\mathrm{~d}$ & $7.55(\mathrm{~m})$ & $\mathrm{C} 3$ \\
137.7 & $\mathrm{~s}$ & - & $\mathrm{C} 14$ \\
149.6 & $\mathrm{~s}$ & - & $\mathrm{C} 8$ \\
157.7 & $\mathrm{~s}$ & - & $\mathrm{C} 1.5$ \\
160.3 & $\mathrm{~s}$ & - & $\mathrm{C} 6$ \\
162.5 & $\mathrm{~s}$ & - & $\mathrm{C} 7$ \\
$-\mathrm{NH}$ & - & $10.9(\mathrm{~s})$ & $\mathrm{a} . \mathrm{b}$ \\
\hline
\end{tabular}

"data determined by DS:PT. "data detemined bx. IIMQC.

showing nOes because it has only seven protons. As a result. structural studies on bistrifluron using NMR could be focused on its complete assignments of the ${ }^{1} \mathrm{H}$ and ${ }^{13} \mathrm{C}$ NMR data. There are fourteen ${ }^{13} \mathrm{C}$ signals in the ${ }^{13} \mathrm{C}$ NMR spectrum. Their multiplicities were determined by DEPT. $\mathrm{C} 2 / \mathrm{C} 4$ and $\mathrm{Cl} / \mathrm{C} 5$ were determined based on the interpretation of DEPT. Since the correlation between $\mathrm{H} 2 / \mathrm{H}+$ and $\mathrm{H} 3$ was observed in COSY, $\mathrm{H} 3$ was detemined. $\mathrm{C} 6-\mathrm{Cl} 6$ were assigned by HMBC. Becalse bistrifluron includes several quaternary carbons in order to observe long ranged coupling between the carbon and proton signals. HMBC applied by a delay time for a long ranged coupling of $70 \mathrm{~ms}$ was carried out. Complete assigiments of the ${ }^{1} \mathrm{H}$ and ${ }^{13} \mathrm{C}$ NMR data are listed in Table 2.

Molecular modeling. The minimum energy conformation of bistrifluron is shown in Figure 4 . The bond lengths, bond angles. and torsion angles determined by molecular modeling calculations are compared with X-ray crystallographic data.

The results reveal that the conformer with two ketone groups placed at the same direction has higher total energy of $10 \mathrm{kcal} / \mathrm{mol}$ than the conformer placed at the opposite direction. While the torsion angles N1-C8-N2-Cy. C6-C7$\mathrm{Nl}-\mathrm{C} 8$, and $\mathrm{C} 5-\mathrm{C} 6-\mathrm{C} 7-\mathrm{Nl}$ determined by $\mathrm{X}$-ray crystallography were $175.2^{\circ},-171.3^{\circ}$. and $-56.6^{\circ}$. those calculated using molecular modeling were $168.2^{\circ}$. 170.34. and $-174.04^{\circ}$. respectively: The values of fomer two torsion angles obtained by

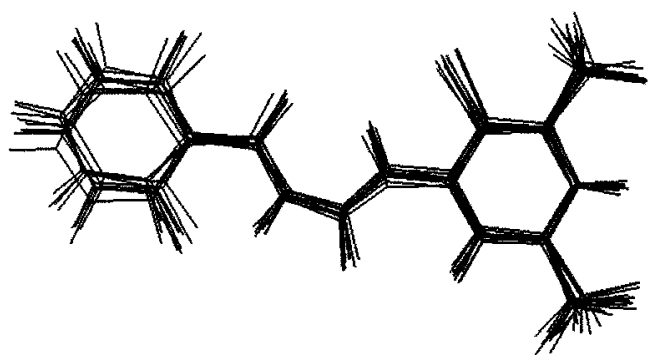

Figure 4 . The superimposed structures of bistritluron obtained by molecular modeling.

molecular modeling agree with those by X-ray crystallograplyy. It can be considered that two torsion angles N1-C8-N2-C9 and C6-C7-N1-C8 are close to the plane because they have double bond character. But in case of X-ray cry stallography two rings are twisted by only $52.6^{\circ}$, and in case of molecular modeling they are more twisted by $15.5^{\circ}$. While when the compound is placed at solid state two rings are twisted. when it is placed in vacuo two rings are positioned almost at the same plane.

Acknowledgment. This work was supported by BK21 project in part. Authors thank Dongbu-hannong Co. for financial support. All NMR measurements by a Bruker Avance 400 spectrometer system were partially supported by Shared Research Equipment Assistance Program $200 \mathrm{l}$ of Korea Basic Science Institute. The molecular modeling experiment was partially supported by nuisistry of information and communication through national grid infrastructure implementation project. Dr. Rhee thanks for the grant by Korea Research Foundation (KRF-2000-015DP0286).

\section{References}

1. Nakagawa. Y.: Izumi. K.: Oikawa. N.: Kurozumi. A.: Iwamura. H.: Fujila. T. Festic. Biochem. Fhrsiol 1991, t0. 12.

2. Song. C.: Shin. W. K.: Cho. K. Y. Korean J. Pextic. Sici. 2000. . 63.

3. Sheldrick. G. M. Acta Crystallogr. 1990. .t46. 467.

4. Sheldrick. G. M. In SHEL V 93, Irogram for the refinement of orystat Stuctures. University of Göttingen: Germany: 1993.

5. Dodrell. D.: P'egg. D.: Bendall. M. J Maght Re'son. 1982. fS. 323.

6. Bax. A.: Freeman. R. J M Jaght. Re'sont. 1981. t3. 333.

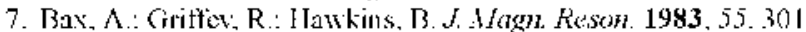

8. Bax, A.: Summers. M. J. Am. Chem. Soc. 1986. 108. 2093.

9. Tumer. D. I.. J. Magn. Reson. 1985. 61. 28. 